eugametos Mitra; the cytology of colonial Volvocales of south-eastern England; the unusual nature of the Dinophycean nucleus; the taxonomy of the Cryptophyceae; etc.

It is clear from this Bulletin that notwithstanding, or perhaps even as a result of, the recent emphasis on other aspects of phycology, work on the morpho$\log y$ and life-histories of the algae is being pursued with undiminished enthusiasm, and there can be no doubt that many stimulating problems in this field will still arouse the interest of future students of the algae.

A. Alilsopp

\title{
THE INSTITUTE FOR SCIENTIFIC RESEARCH IN CENTRAL AFRICA
}

$\mathrm{T}$ HE Institut pour la Recherche Scientifique en Afrique Centrale, founded in 1947, has five main centres in the Congo at Lwiro, Uvira, Astrida, Mabali and Elizabethville, and a number of sub-stations for field studies at Tshibati, Irangi, Uwinka (Ruanda), Bugesera and Mutara.

The twelfth annual report of the Institute *, written in French, is an impressive document of 253 pages illustrated by an appreciable number of photographs. It is divided into three sections dealing respectively with administration, including the report of the director-general, Prof. L. Van den Berghe, on the work of the Institute; review articles on the work of the Institute in certain broad fields, and abstracts of scientific papers written by the staff or those who have been in some way associated with it, and published in 1959.

The first part of the report gives, in addition to the report of the director-general, details of the constitution of the Institute, membership and activities of the various scientific committees connected with its work, and a financial statement. The report of the director-general includes not only details of the scientific activitios but also lists of visitors to the Institute during the course of the year and details of construction work carried out to extend and improve the various centres. One feels that much of the information given in the first forty pages of this administrative section of the report would be more appropriately situated in an appendix, thus leaving the report to deal primarily with the scientific work carried out. The same is true of the financial report, which is placed between the account of research activities and the section of the report devoted to review articles.

The range of scientific work covered by the Institute is vast. The report of the director-general gives details of work being carried out in the following fields: experimental zoology, including the capture, study and breeding of wild animals such as buffalo, chimpanzee and mountain gorilla; entomology;

* Institut pour la Recherche Scientifique en Afrique Centrale, Bruxelles. Douzleme Rapport Annuel, 1959. Pp. 253. (Bruxelles: parasitology, with particular reference to trypanosomiasis; human pathology including kwashiorkor, the effocts of vitamin $A$ and the role of different classes of lipids in human nutrition; anthropology, sociology and languages; archæology; hydrobiology and hydrology; plant geography, ecology and physiology; seismology and vulcanology. An observatory was under construction on Mount Tumbwe.

The four review articles which constitute the second part of the report are concerned with the part played by the Institute in the study of feeding and nutritional problems; hydrobiological research on Lake Tanganyika; physical sciences including seismology, vulcanology, solar-terrestrial phenomena and astrophysics; human sciences including cultural and physical anthropology, economics, African languages, prehistory and history. The list of scientific papers written by the staff and associates of the Institute during 1959, which is given in the final section of the report, covers the whole range of the work of the Institute. Abstrects of varying length are given for more than half the 103 papers listed.

Two main impressions are gained from reading these reviews and abstracts, and indeed from the report as a whole. First, that the Institute was attempting to cover too wide a scientific field for all aspects of its work to be really effective. Secondly, that it is not a pure research institute but is very much applied in its approach. The latter would seem to be very desirable in an institute working in an underdeveloped country where not only are the basic facts about the terrain and habits of the people largely unknown, but where also the applied work can only be carried out in the territory itself.

It is unfortunate that the Institute for Scientific Research in Central Africa, with the present diffieulties in the Congo, appears to have more or less ceased operations. It will be a considerable loss both to the Congo and to all underdeveloped territories if it does not continue, and it is to be hoped that the offorts being made at present by the authorities in the Congo to carry on the type of work started by the Institute will prove successful.

S. S. BAMptoN

\section{HORTICULTURAL RESEARCH}

$\mathrm{H}$ ORTICULTURE, either as an art or industry, is far more concerned with the behaviour of individual plants than its more extensive congener agriculture. It is an ideal setting for research on applied botany, and almost all agricultural problems must first be investigated on a horticultural scale. The garden itself poses urgent problems for scientific solution and they can be investigated effectively with either ecological directness or with the full majesty of basic science. There is, moreover, an immediate outlet for practical results, and the stringent, unsubsidized economics of the industry impose a rather more searching test of significance than even those of the mathematician. Horticulture in fact lies, in the research sense, at the cross-roads of many sciences-crop protection, plant physiology, genetics, and taxonomy - in addition to forestry and agriculture. It is rather surprising that there have 